症 例

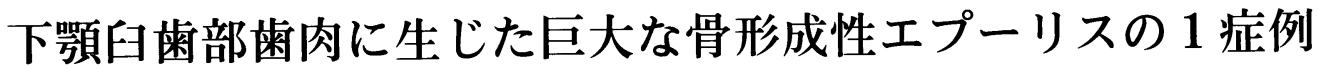

\author{
空 䦥 裕 紀 尾原清司佐々木秀和 \\ 田部 眞 治 吉 村 安 郎
}

要旨：エプーリスは歯肉に生じた良性の限局性腫瘤の総称で, 比較的よくみられる疾患である。今回われわれは, 下顎 歯肉に発生した巨大な骨形成性エプーリスの 1 例を経験したので報告する。患者は 78 歳, 女性。右側下顎臼歯部歯肉 の腫瘤形成を主訴に来院。腫瘤は右側下顎臼歯部歯肉にあり, 弾性硬, 有茎性であった。表面は平滑であるが数か所の 潰瘍を伴っていた。

$\mathrm{X}$ 線写真では, 腫瘤内に小さな放射線不透過性陰影が散在し, 多くの石灰化物を思わせた。また, 生検組織所見は炎 症性肉芽組織であった。全身麻酔下に腫瘤摘出術を行ったところ, 腫瘤下に歯槽窩を確認した。摘出物は約 $61 \times 48 \times$ $40 \mathrm{~mm}$, 重さ約 $50 \mathrm{~g}$ であり, 組織学的には膠原線維の増生を伴う線維性結合組織と, 骨芽細胞に囲まれた層板骨が散在 していた。

最近 10 年間で長径 $3 \mathrm{~cm}$ 以上の巨大なエプーリスについて 20 症例の文献を渉猟することができ，中でもわれわれの 症例は中程の大きさであった。自験例を含めこれらの報告について, 患者の年令, 性別, 病変の部位, 大きさ, 治療に ついて考察した。

キーワード : 巨大な腫瘤, 骨形成性エプーリス, 文献的考察

\section{緒言}

エプーリスは歯肉部に生じた良性の炎症性, 反応性限局 性腫瘤の総括的臨床名として広く用いられ，まれな疾患で はない。しかし，その発生部位が歯肉部であることより， 早期に発見され処置されるため大きな腫瘤となることは比 較的まれである。

われわれは，巨大な骨形成性エプーリスの 1 症例を経験 したので報告する。

\section{症例}

患者： 78 歳，女性。

初診: 平成 13 年 10 月 17 日。

主訴 : 右側下顎臼歯部の腫瘤形成。

既往歴: 平成 13 年 10 月 24 日, 良性髄膜腫があること が明らかとなったが特に加療しないことになった。

家族歴 : 特記事項なし。

現病歴: 平成 12 年 4 月頃, 右側下顎歯肉部に腫瘤を自 覚するが疼痛を認めないため放置していた。腫瘤は次第に 増大し, 平成 13 年 9 月には, 腫瘤と同じ部位に 1 歯残存 していたが自然脱落した。腫瘤の増大が継続するため平成 13 年 10 月 4 日, 近歯科医を受診し, 同日精査加療目的に

島根医科大学医学部歯科口腔外科学講座 (主任 : 吉村安郎教授) 〔受付: 2003 年 1 月 31 日, 受理 : 2003 年 3 月 28 日]
当科紹介初診となった。

現症 :

全身所見；体格中等度，栄養状態良好。

口腔外所見; 顔貌は左右非対称で, 右側煩部から下顎部 の腫脹により右鼻唇溝がやや消失し, 右口角が伸展されて いた（写真 $1, A)$ 。

右側顎下部に大豆大，小豆大 2 個のリンパ節を，左側顎 下部には大豆大リンパ節を 1 個可動性, 弾性やや硬として 触知した。

口腔内所見 ; 右側下顎小臼歯部から白後部かけて約 60 $\times 50 \times 40 \mathrm{~mm}$ 大, 弾性硬の有茎性, 可動性腫瘤を認めた。 腫瘤の表面は平滑, 色調は正常粘膜色, 一部に白色, 発赤 部が混在しており，多発性に小潰瘍を認めた（写真 $1, \mathrm{~B} ） 。$ 画像所見 : パノラマ X 線写真では右側下顎小臼歯部歯 槽骨の腫瘤の圧迫によると思われる骨吸収像と, 腫瘤内部 に大小不同のX線不透過像が散在して認められた。

CTでは右側煩部から下顎にかけて辺縁比較的平滑な腫 瘤を認め, 内部は不均一で前方内側部に石灰化物と思われ る像が散在していた。有意なりンパ節腫大はなかった（写 真 $1, \mathrm{C})$ 。

臨床検查所見 : WBC $9310 / \mathrm{mm}^{3}, \mathrm{RBC} 397 \times 10^{4} / \mathrm{mm}^{3}$, $\mathrm{Hgb} 9.9 \mathrm{~g} / \mathrm{dl}, \mathrm{CRP} 2.8 \mathrm{mg} / \mathrm{dl}$ であった。他の血液および 生化学検査において特記すべき項目は見いだせなかった。

臨床診断 : 右側下顎小臼歯部より臼後部にいたる歯肉エ プーリス。

処置及び経過：平成 13 年 10 月 26 日腫瘤表面 3 か所よ 


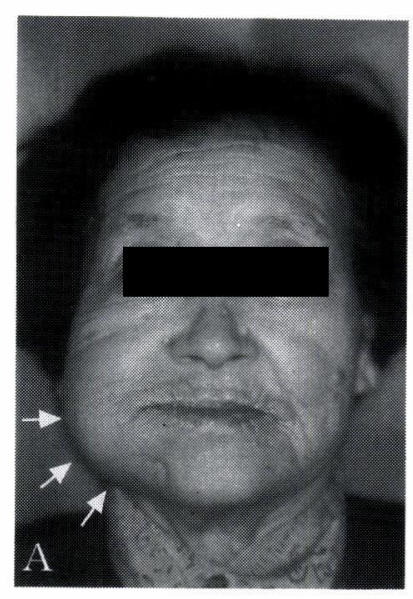

A : 顔貌写真
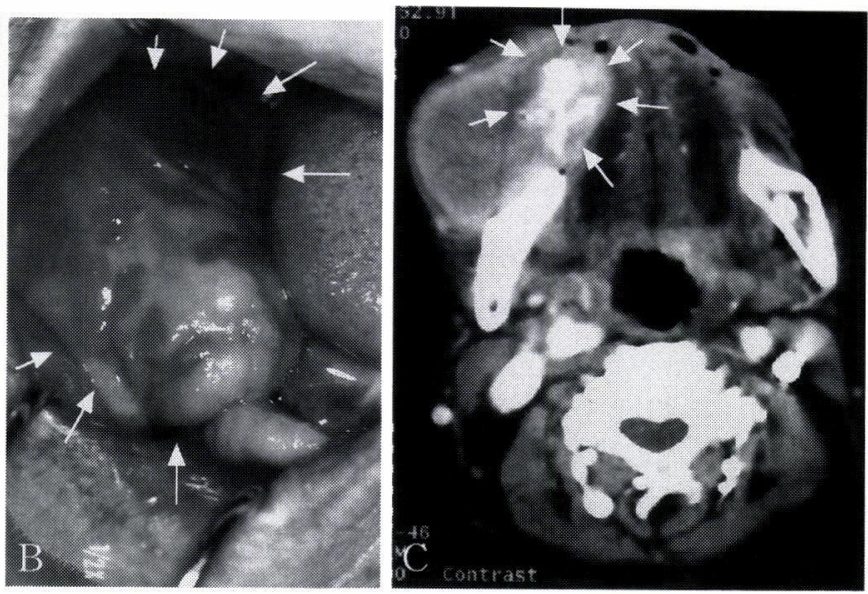

写真 1 初診時写真 右側煩部から下顎体部へかけての腫脹をみとめる。

B : 口腔内写真 右側下顎小臼歯部から臼後部へかけて弾性硬，有茎性の大きな腫瘤が口腔内を占居している。

C : 術前 CT 写真 (Axial) 石灰化物の存在を示唆する像 (矢印)。

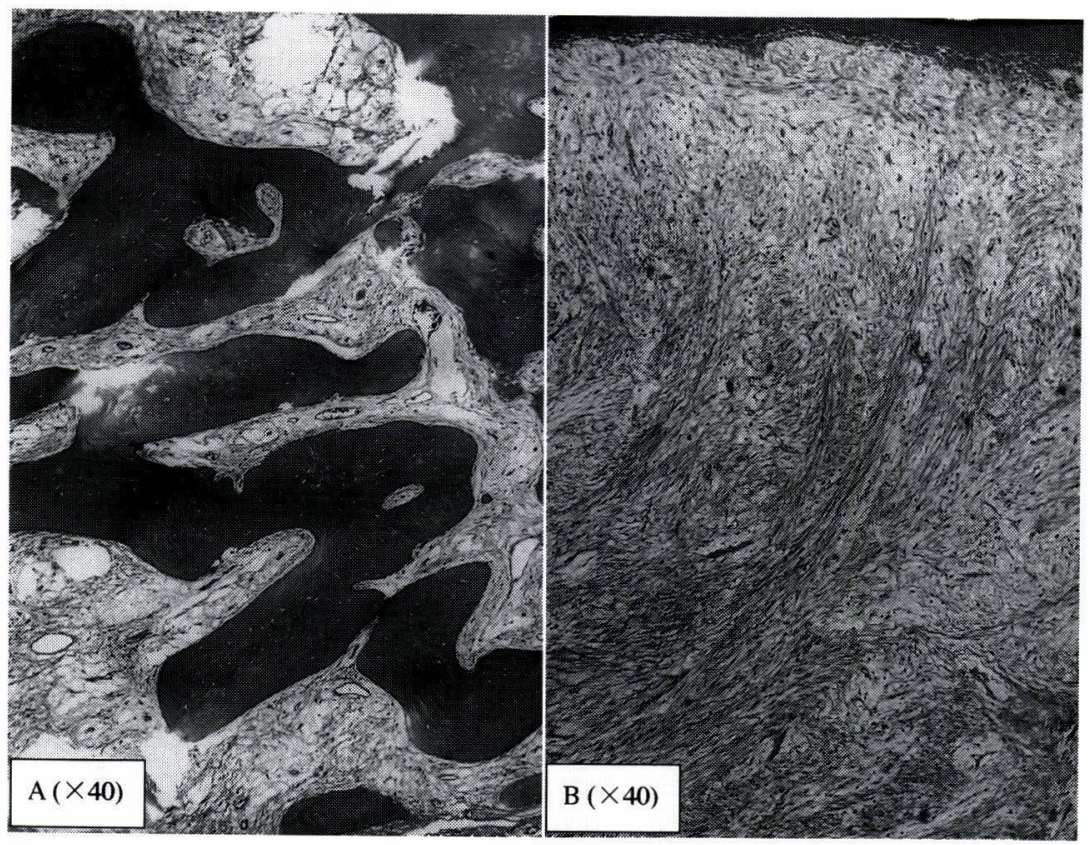

写真 2 病理組織像

A：骨芽細胞に取り囲まれた層板構造を有した梁状の骨組織を認める $(\mathrm{H}-\mathrm{E}$ 染色， $\times 40)$ 。 B : 上皮下組織は広範な線維化を示し, 膠原線維の増生がある (H-E 染色, $\times 40)$ 。

り生検を行ったが, 病理組織学的にはいずれも「炎症性肉 芽組織」であり，悪性所見は認められなかった。

同年 11 月 2 日全身麻酔下に腫瘤摘出術を施行。腫瘤は 431 相当部歯槽堤粘膜に基部を有し，これを含めて一塊と して摘出した。腫瘤下の歯槽骨には $\overline{3}$ または $\overline{4 \mid}$ の抜歯窩
と思われる骨の陥凹を認めた。術後 8 か月の現在, 再発の 徵候なく経過良好である。

摘出物所見: 大きさ約 $61 \times 48 \times 40 \mathrm{~mm}$, 重量約 $50 \mathrm{~g}$ 。割 面は全体的に黄白色を呈し，充実性であった。

病理組織学的所見：上皮下組織は広範な線維化を示し, 


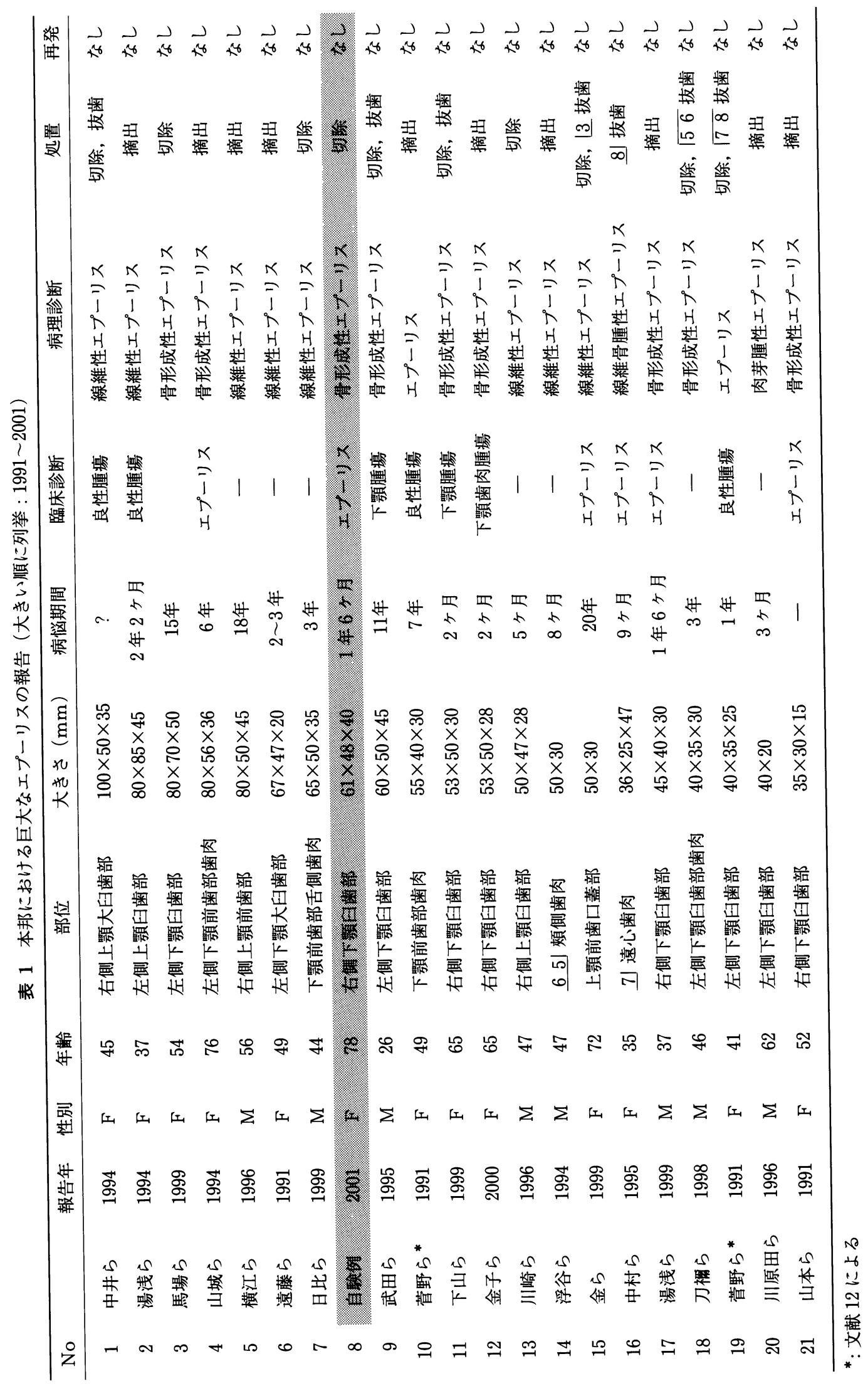


骨形成の認められない腫瘤の後方部実質は膠原線維の増生 をともなう線維性結合組織で満たされていた（写真 $2, \mathrm{~B}) 。$ また表層から離れた歯槽骨側に，骨芽細胞に囲まれた層板 構造の梁状骨組織を認めた（写真 $2, \mathrm{~A})$ 。骨形成周囲には 粘液様, 脂肪様変性が認められ, 骨髄の形成も疑わせた。 病理組織診断：骨形成性エプーリス

\section{考察}

エプーリスの多くは炎症性ないし反応性の増殖物とされ， 真の腫瘍であることは少ない。20３0 歳代が，全体の約 $40 \%$ を占め, 男女比は $1: 2.2$ の割合で女性に多い。好発 部位は上顎前歯部といわれている。病理組織学的には, 肉 芽腫性, 線維性, 血管腫性, 線維腫性, 骨形成性, 巨細胞 性に分類されており ${ }^{1)}$ ，本邦での骨形成性エプーリスの全 エプーリスに占める割合は, 石川ら ${ }^{1)}$ は $7.8 \%$, 石田ら ${ }^{2)}$ は $19 \%$ ，好士 ${ }^{3)}$ は $4.6 \%$ と報告している。今回われわれが渉 猟し得た過去 10 年間の長径 $30 \mathrm{~mm}$ 以上のエプーリスの報 告は, 自験例を含め 21 例であった ${ }^{4-22)}$ (表 1 )。これら 21 報告例を見る限り，最小の症例でも最大径が $35 \mathrm{~mm}^{22)}$ あった。また， 21 例中骨形成性エプーリスは 8 例あり全 エプーリスに占める割合に比較すると多く，これは「30 $\mathrm{mm}$ 以上のエプーリスは骨様組織を形成する物が多い」と いう報告 ${ }^{23,24)}$ に矛盾しない。これら過去の報告例とその 考察を検討すると, 長径 $30 \mathrm{~mm}$ を超えるエプーリスは, 巨大という表現には議論があるところであるが，今回は $30 \mathrm{~mm}$ 以上をもって巨大と定義することとした。その内, 自験例の長径 $60 \mathrm{~mm}$ は報告の中でも上位の大きさとなる。 巨大エプーリスの性別は, 男性 8 例, 女性 13 例であり, 全エプーリスの性差と変わらないと考えられた。発生年齢 は, 平均 51.5 歳となり, エプーリス全体から考えるとや や高齢であると思われるが, 21 症例のエプーリスの大き さと年齢には関係は見いだせず，病悩期間の長いものが大 きい傾向にあった。発生部位は好発部位といわれている上 顎前歯部が最も少なく, 上下顎とも臼歯部に好発している。 これは上顎前歯という審美性の重視される部位では巨大に なる前に処置がなされるからであろうと思われる。

臨床診断では 21 例中 4 例に悪性腫瘍が疑われた。本症 例も腫瘤の増大が比較的速やかで, 表面に一部潰瘍をとも なっていたため，まず生検を施行し，良性であることを確 認した。このような術前の精査により正しく診断し，これ により過鄱な治療を防ぐことができるのではないかと思わ れる。

エプーリスの発生原因は未だ明らかではなく, 全身的因 子としては先天性の体質的素因やホルモンの関与が挙げら れ, 局所的因子としては不良補綴物, 歯の鋭縁, 口腔衛生 上の環境的因子も考えられている ${ }^{24)}$ 。本症例では口腔清
掃状態が悪く，エプーリス発生部位に，自然脱落する様な 歯が存在していたこと，またエプーリス基部歯槽骨に歯槽 窩が確認できたことより, 残存していた歯と, 口腔清掃不 良による慢性刺激がエプーリス発生になんらかの役割を果 たしたと考えられる。

エプーリスにおける硬組織形成の成因はさまざまな報告 があり，未だ解明されていない。歯根膜組織中の骨形成能 を有する細胞に由来するという説 ${ }^{26)}$, 潰瘍が治瘉する過 程で石灰化や骨化をともないつつ線維芽細胞様細胞が成熟 して線維性組織になるという説 ${ }^{24,27)}$ などがある。また最 近，エプーリスの一つである calcifying fibroblastic granuloma の石灰化, 骨形成は, 様々な条件によって非 造血器系の周皮細胞より直接形成されていることを示唆す る結果が, 免疫組織染色を用いて示された ${ }^{28)}$ 。本症例に おいては, エプーリス発生時に歯が残存していたこと, 骨 形成部位が歯槽骨に近く，歯槽窩相当部であったことより 歯根膜組織中の骨形成能を持った細胞の関与が大きいよう に思われたが, 線維成分の豊富な領域に比較し, 骨形成領 域では血管成分が豊富であることは興味深い。

\section{結 語}

今回われわれは，巨大な骨形成性エプーリスの 1 症例を 経験したので報告した。

\section{文献}

1) 石川梧朗 監修; 口腔病理学 II, 改訂版, 永末書店, 京都, 1982, 229-240 頁.

2) 石田 武, 長谷川清, 他 : エプーリスの分類と自験例 160 例 の集計観察. 口科誌 $30: 14-23,1981$.

3）好士和夫：エプーリスの臨床的ならびに組織学的研究. 口病 誌 $26: 1662-1682,1959$.

4）中井道明, 紀平晋也, 他 : 巨大な線維性エプーリスの一例. 京府医大誌 $103: 243-248,1994$.

5）湯浅秀道，村田晴彦，他 : 顔貌変形をきたすほど巨大化した エプーリスの 1 例. 日口外誌 $40: 807-809,1994$.

6）馬場信行, 松尾長光, 他 : 顔貌変形をきたした巨大な骨形成 性エプーリスの 1 例。口科誌 $48: 92-96,1999$.

7）山城正司, 藤井英治, 他 : 下顎に発生した巨大なエプーリス の 1 例 (抄). 日口外誌 $40: 563,1994$.

8）横江秀隆, 青木洋大, 他 : 口腔を占有する巨大な上顎線維性 エプーリスの 1 例 (抄). 口科誌 $45: 338,1996$.

9）遠藤美智子, 植木輝一, 他 : 巨大な線維性エプーリスの 1 例 (抄). 日口外誌 $37: 2375,1991$.

10）日比英晴, 中井英貴, 他 : 下堮に発生した巨大なエプーリス の 1 例 (抄). 日口外誌 $45: 149,1999$.

11）武田幸彦, 加藤譲治 : 下顎に生じた骨形成性（骨腫性）エプー リスの 1例. 日口外誌 $41: 835-837,1995$.

12）菖野和彦, 山野井弘充, 他: 下顎に生じた巨大なエプーリス の 2 例. 日口外誌 $37: 1393-1394,1991$.

13）下山哲夫，金子貴広，他：巨大な骨形成性エプーリスの 1 例. 日大歯学 $74: 229-232,2000$. 
14）金子貴広, 村上起人, 他 : 巨大な骨形成性エプーリスの 1 例 (抄). 日口外誌 $46: 1054,2000$.

15）川崎一慶, 石倉信造, 他 : 急速な発育を示し, 口蓋の半側を 占めた線維性エプーリスの 1 例（抄）。口科誌 $45: 344$, 1996.

16）浮谷得子, 高森康次, 他 : 上顎に発生した巨大なエプーリス の 1 例 (抄). 日口外誌 $40: 563,1994$.

17）金 建三, 連 利隆, 他 : 口腔を占有した巨大エプーリスの 1 例 (抄). 日口外誌 $45: 947,1999$.

18）中村英治, 小野貢伸, 他 : 巨大な線維骨腫性エプーリスの一 例. 口科誌 $44: 147-150,1995$.

19）湯浅秀道，杉浦正幸，他：柱状の骨形成を伴う巨大な下顎工 プーリスの 1 例. 日ロ外誌 $45: 718-720,1999$.

20）刀螎大輔, 林 優, 他: 巨大な骨形成エプーリスの 1 例 (抄). 口科誌 $47: 434,1998$.

21）川原田裕子, 中瀬 実, 他: 巨大なエプーリスの一例（抄）. 日口外誌 $42: 629,1996$.

22）山本道直, 田渕順治, 他：下顎臼歯部に発生した巨大な骨形 成性エプーリスの 1 例（抄). 口科誌 $40: 683,1991$.
23）福田容子, 戸塚盛雄, 他: エプーリスの病理学的検討 第 3 報：硬組織形成性エプーリス。 日ロ外誌 $34: 175-178$, 1988.

24）川崎五郎, 空閑祥浩, 他: エプーリスの臨床統計学的観察お よびいわゆる骨形成性エプーリスについて， 口科誌 45 : 80-85, 1996.

25）森 恵造, 浜川裕之, 他：骨形成性エプーリスの 1 症例。 日 口外誌 $34: 1399-1405,1988$.

26）照屋正信，山代正宏，他：上顎に生じた巨大な周辺生化骨性 線維腫について. 日口外誌 $29: 920-925,1983$.

27) Southam J.C. and Venkataraman B.K.: Calcification and ossification in epulides in man (excluding giant cell epulides). Arch Oral Biol 18 : 1243-1253, 1973.

28) Dayoub S., Devlin H., et al.: Evidence for the formation of metaplastic bone from pericytes in calcifying fibroblastic granuloma. $J$ Oral Pathol Med 32 : 232-236, 2003. 


\title{
A case of a large osteoplastic epulis on the mandibular gingiva
}

\author{
Yuki Kuga, Seiji Obara, Hidekazu Sasaki, \\ Shinji Tanabe and Yasuro Yoshimura \\ Department of Oral and Maxillofacial Surgery, \\ Shimane Medical University, School of Medicine \\ (Chief : Prof. Yasuro Yoshimura)
}

\begin{abstract}
Epulis is a general term for inflammatory hyperplasia of the gingiva. It is a common disease in the oral region. We reported a case of large epulis on the right premolar to molar gingiva of the mandible in a 78-year-old female. She complained of tumor formation on the right molar gingiva of the mandible, which was elastic hard, pedunculate, and had a smooth surface with multiple small ulcers.

Radiographically, small radiopaque areas were scattered in the mass, suggesting that the tumor had many calcified areas. Tissue biopsy revealed an inflammatory granulation tissue containing calcified bodies. After simple extirpation of the epulis, alveolar fossa was confirmed under the tumor.

Histopathologically, the specimen, which was $61 \times 48 \times 40 \mathrm{~mm}$ in size and $50 \mathrm{~g}$ in weight, showed fibrous connective tissue including proliferation of collagen fiber and scattered lamellar bones surrounded by osteoblasts.

We could identify 20 previous reports of large epulides over the past 10 years, and our case proved to be of medium size among them. In this paper we reviewed patient's age, sex, position, size, and treatment of the previously reported cases.
\end{abstract}

Key words : large mass, epulis osteoplastica,review of literature

Requests for reprints to: Dr. Kuga Y., Department of Oral and Maxillofacial Surgery, Shimane Medical University School of Medicine, 89-1, Enya-cho, Shimane, 693-8501 Japan. 